\title{
THE IMPORTANCE OF THE PRE SEPTEMBER 11 PERIOD IN EXPLAINING AZNAR AND BLAIR'S ADOPTION OF A PRO-US FOREIGN POLICY
}

\section{INTRODUCTION}

The close relationship between José María Aznar and Tony Blair is often claimed to have been forged after the attacks in the United States on September 11. Their relationship was, however, established beforehand, and led to a shared approach to foreign policy in the European Union and on the global stage. This alliance was represented by an increasingly shared vision of the world, an emerging desire to pull Europe in a more transatlantic direction and the extent to which both leaders held strongly supportive views of the United States. In spite of the importance of September 11, it is the period from Aznar's election victory in 1996 up until 10 September 2001 which is particularly significant in explaining how the two leaders became so closely aligned in their foreign policy preferences.

Identifying the shared preferences between Aznar and Blair is instrumental in explaining how their foreign policy began to shift so significantly in a transatlantic direction even before the events of September 11. Personal preferences are vital because foreign policy decision-making was dominated by Aznar and Blair to such an extent that the influence of ministers was limited. To understand the reasons for Aznar and Blair's adoption of a pro-US foreign policy it is, therefore, necessary to focus on their actions, opinions, and policy preferences, and to examine the role of other ministers, parliament, or institutions only when any of them influenced either leader’s foreign policy. 
This article argues that while September 11 was extremely important in explaining Aznar and Blair's adoption of a pro-US foreign policy, other factors during the period leading up to that date were very important in explaining the close relationship between Aznar and Blair within Europe and on the global stage. It aims to fill a gap in the existing literature, which explains Aznar and Blair's support for US foreign policy separately, and tends to focus on the impact of September 11 and subsequent events. This article summarises the background in terms of events which were taking place during the period 3 March 1996 - 10 September 2001, before outlining a brief account of the method used to identify the relevant and salient factors from speeches, newspapers, and documents. Each of these factors is subsequently assessed, in order to explain how Aznar and Blair ended up on the path to adopting a pro-US foreign policy even before the attacks on September 11. The article concludes by highlighting why it is imperative for this period to be taken into account when explaining Aznar and Blair's support for the United States from a comparative perspective.

\section{BACKGROUND AND METHOD OF ANALYSIS}

The period from Aznar’s general election victory on 3 March 1996 up until 10 September 2001 was characterized by Aznar and Blair bringing the Partido Popular and the Labour Party into government after extensive periods in opposition. This context is an essential component in providing a complete explanation of Aznar and Blair's behaviour during their first term in office. Aznar and Blair's main concern was to ensure that voters perceived their governments to be competent, in order to increase their chances of gaining a second term in office. This was 
reflected, however, in their approach to domestic policy. In terms of foreign policy, both leaders acted with a significant amount of freedom.

European reform dominated Aznar and Blair's foreign policy. The desire of both leaders to steer the European Union down a more neo-liberal economic path saw the two leaders form a close alliance. This alliance often put them at odds with the leaders of France and Germany, and led to clashes with the main opposition party in the Cortés and House of Commons respectively, albeit for different reasons. Beyond the European Union, Aznar and Blair faced foreign policy challenges in the form of Iraq and Kosovo. It was towards the end of this period that the two leaders asserted their control over foreign policy in particularly emphatic style. Blair assumed a leading role in the Kosovo crisis, building a close team of advisers on foreign policy around him, while Aznar established his own Foreign Affairs Council, which, in addition to the Partido Popular obtaining a majority in the Spanish general election in 2000, augmented his ability to dominate foreign policy decision making.

The method used to identify the factors explaining Aznar and Blair's adoption of a pro-US foreign policy is Qualitative Content Analysis (QCA). QCA describes the meaning of qualitative material and classifies relevant aspects of this material into categories which comprise a coding frame (Schreier, 2012: 1). In the case of this study, the coding frame is applied to speeches and newspaper articles to identify which factors are the most salient in terms of explaining Aznar and Blair's adoption of a pro-US foreign policy, in the process highlighting those whose significance has been overlooked or understated in the secondary literature. QCA achieves this objective by ensuring that all the data from the material is examined (Schreier, 2012: 5). This is important because it ensures that any information which 
fails accord with preconceived explanations is not overlooked (Schreier, 2012: 5). This is the main reason for choosing QCA ahead of other qualitative methods. The fact that it evaluates the material on its own merit, instead of applying pre-existing explanations from the secondary literature means that factors explaining Aznar and Blair's foreign policy are identified by generating a coding frame inductively from the speeches and newspaper articles, rather than checking for the presence of predetermined factors to test the findings presented in the secondary literature. This is crucial to this investigation because the secondary literature views September 11 as the most critical factor in explaining Aznar and Blair’s support for US foreign policy, but thanks to QCA, this study is able to highlight that others factors prior to the attacks are highly influential in explaining Aznar and Blair's foreign policy. The other reason for choosing QCA is that, compared to other qualitative methods, it reduces the amount of data after the coding frame has been applied, and strengthens the chance of finding new data when comparing across cases, resulting in information being increased at an aggregate level (Schreier, 2012: 7-8). This study is concerned with uncovering new factors and re-examining the importance of others in explaining the Aznar-Blair relationship, thus QCA offers an immensely valuable approach.

QCA is employed to examine the speeches made by Aznar and Blair and the newspaper articles referenced in this study. The rationale for choosing the speeches was that they had to have been made by Aznar or Blair, and that they had to include content pertaining to their foreign policy. For reasons of triangulation, the newspaper articles were chosen from newspapers on opposing sides of the political spectrum. Articles on the foreign policy of both leaders were taken from ABC, El País, The Guardian and The Times. El País and The Guardian were more critical of Aznar and Blair's foreign policy, while ABC and The Times were more supportive of the foreign policy of both leaders. The newspapers provided behavioural and contextual 
information about both leaders, making it easier to identify salient factors and reach accurate conclusions regarding their adoption of a pro-US foreign policy.

The interviews are not examined using QCA because there were too few interviewees for it to be used. The interviewees included in this investigation were all chosen based on their role in either the Aznar or Blair administration. These roles included having been members of the government, advisers to Aznar or Blair, ambassadors to either Spain or the United Kingdom or members of either country's diplomatic service. The information obtained from the interviews is used in conjunction with the secondary literature to support a number of the key arguments made in this article.

\section{ANALYSING AZNAR AND BLAIR'S FOREIGN POLICY}

There are five salient factors which explain Aznar and Blair's adoption of a pro-US foreign policy before September 11. These are: EU reform, parliamentary and party support, terrorism, weapons of mass destruction and influence on the global stage. The reasons explaining the importance of these factors is addressed below:

\section{REFORM OF THE EUROPEAN UNION}

The partnership between Aznar and Blair in Europe was the starting point for their mutual support, which was to expand into backing the United States on foreign policy issues. The key 
finding to emerge regarding Aznar and Blair's approach to Europe was the extent to which they shared similar perspectives about how the economy of the European Union should be reformed. This bilateral relationship was enhanced by the emergence of unexpectedly warm personal links between Blair and Aznar; links which were formed when Aznar invited Blair and his family to holiday at the Coto Doñana after Blair had successfully brokered the Good Friday agreement, an agreement which held great interest for Aznar, who faced the similar conundrum of how to deal with the Basque problem (Brighty, 2012). This closer relationship subsequently became discernible in various European fora, and appeared to grow over the following months, which was very significant, given that Blair was unable to gain the support of Chirac and Schröder for his proposed new direction for the European Union (Brighty, 2012).

Blair’s position regarding European Union reform initially centred on his desire for the United Kingdom to play a much more active role in the European Union. Jay (18/10/2011) explained that this new approach revolved around Blair looking for allies who would support him in pushing his economic reform agenda for the European Union, and that this is why he was able to build relations with right wing leaders, such as Aznar. Blair thus practised a form of bilateralism, which involved working with countries whose interests coincided with those of the United Kingdom, which is why he formed a partnership with Aznar regarding economic reform (Smith, 2005: 709, 710). This process of building new alliances, known as 'step change', was all part of a new tactic to increase the amount of bilateral contact with medium and small member states to help the United Kingdom to win arguments and set the agenda (Black, 2000: 1). It was his warm relationship with Aznar which was, moreover, the most conspicuous example of 'step change', and was indicative of the strength of the alliance between the two leaders (Black, 2000: 1). 
Blair's proactive foreign policy towards Europe coincided with Aznar's approach towards economic reform, particularly in relation to the Lisbon Agenda (Smith, 2005: 704). Blair was a passionate advocate of economic reform. The special summit in Lisbon on this subject was an important development which Blair cited as showing that European reform was shifting in a direction to suit his preferences; even going so far as to describe the policy shift as a sea change in European economic thinking (Hansard, 2000a: 1, 5). This reform, however, attracted little support from France and Germany. While Schröder was initially supportive, neither he nor Chirac ultimately shared this vision for the EU's economic policy. Blair's hopes that Schröder would be an ally on economic reform were, consequently, never realised, and it was dubious that the French would ever have agreed to such reform, which explains why Blair sought an alliance with Aznar (Anon, 2011).

Economic reform was a key element of Aznar's European policy. It was this drive to reform which represented the crucial link between Aznar and Blair; a point which was stressed by the Spanish leader (Aznar, 2004: 198). Spanish conservatives viewed the European Union as a large integrated market in which Spain would be able to prosper, as well as achieve national goals, for example, becoming a member of the G8 (Torreblanca, 2001: 20). Spain's membership of the EU also reflected their agenda of modernising the Spanish economy (Pachego Pardo, 2012: 32). The result was that once the Partido Popular assumed the mantle of government, it became even more Europeanized than had been the case when it was in opposition (Paheco Pardo, 2012: 33). Like Blair, Aznar wanted the European Union to adopt a liberal approach to the markets (Aznar, 1994: 169). This shared vision of the future of the EU culminated in the two publishing a joint article on EU economic reform in the Financial 
Times and El Mundo, which emphasised the strong bond between the two leaders. On more than one occasion, Aznar indicated that such joint Anglo-Spanish proposals were positively received by other EU member states (Congreso de los Diputados, 1998b: 11018; Aznar, 2000b: 10), however, at the Stockholm European Council meeting, he added that it had not been possible to go as far as he had wanted, owing to the reticence of a minority of member states (Congreso de los Diputados, 2001: 3669, 3671). While Aznar did not refer to any member state specifically, the Irish Prime Minister revealed that it was principally France which had the greatest difficulty with the liberalisation project (Dáil Eireann Debate, 2001: 8). The fact that the United Kingdom was more receptive to Aznar's preferred economic model for the European Union turned Spain away from its traditional position in Europe, thus highlighting the extent to which Aznar and Blair were establishing a close relationship before the attacks on September 11.

The alliance between Aznar and Blair over EU reform was not a coincidence; it was a direct result of a shared perspective and outlook on Europe. The unwillingness of France and Germany to agree to the economic reforms that Aznar and Blair wanted was a stimulus towards the two beginning to build an alternative axis of power, based on neo-liberal reforms. Having established common ground in one area of external relations, it became increasingly clear that were other areas of foreign policy where they held similar views, leading to the development of a closer alliance regarding these areas, many of which related more specifically to the United States. It is, therefore, crucial not to overlook their close relationship in Europe, for it was the building block on which their foreign policy was constructed. 
This factor is very important because the lack of domestic opposition to Blair and Aznar's foreign policy in relation to the air strikes against Iraq in 1998 and intervening in Kosovo in 1999 meant that there were no domestic barriers to adopting a pro-US foreign policy. Blair's support for the air strikes against Iraq was also helped by the fact that a Commons debate was held only after the military action had begun (Kampfner, 2004: 301), while at no stage was Aznar's foreign policy constrained by the regional parties which supported his minority government. This finding challenges the argument put forward by Gunther and Montero (2009: 136-137) that the Partido Popular had its legislative freedom restricted by requiring the support of three regional parties to pass its legislation. While this is likely to have been true in relation to areas of domestic and European policy, it was not the case as far as foreign policy was concerned. This lack of domestic constraint explains why both leaders were able to be so supportive of the United States.

The one area where both Aznar and Blair came under pressure, albeit for different reasons, was regarding their policy on the European Union. Blair was criticised by the Conservatives for being too pro-European, while Aznar was criticised by the Socialist Workers’ Party/Partido Socialista Obrero Español (PSOE) for not being sufficiently pro-European. Both Aznar and Blair were, therefore, fighting against the main opposition parties in their own countries, but in the process finding common ground with each other in Europe. In forging this partnership, they were becoming closer to the United States, which made it more difficult for the pro-US Conservative Party to credibly criticise Blair's foreign policy, whilst Aznar's objective of enhancing Spain's international standing allowed him to counter the PSOE's criticisms, by 
claiming that he was taking Spain into a new sphere of influence which Spain's socialist governments had been unable to achieve.

On the issues of Iraq and Kosovo the Conservative Party consistently and strongly supported Blair's foreign policy, but on the issue of his European policy Blair faced strong opposition from the Conservatives. Their leader, William Hague, pressurised Blair constantly over further integration, as the Conservative position was to stop any further transfer of sovereignty to the European Union (Hansard, 1999d: 2-3; 1999e: 4; 2000a: 3; 2000b: 4). Hague also argued that the European Union was failing to reform, and that it was not addressing critical problems in relation to cohesion funding, enlargement, and the Commission (Hansard, 1999b). He was also critical of Blair's support for the development of any European defence capacity which could be outside the framework of NATO (Hansard, 1999e: 4; 2000b: 4).

Aznar received support from the PSOE for his defence of Spanish interests (Congreso de los Diputados, 1996: 694; 1997: 6667; 2000b: 2490). The Socialists were, however, critical of his conduct, accusing him of behaving like Margaret Thatcher in Europe (Congreso de los Diputados, 1999b: 13064). In the view of the PSOE, Aznar's policies in Europe were causing Spain to lose influence, sending it down the path of a policy of 'less Europe', a position the Socialists could not support (Congreso de los Diputados, 1998a: 9104, 9106, 9107; 1999c: 15127). Aznar's choice to ally with the anti-integrationist United Kingdom, instead of maintaining the previous alliance with the Franco-German axis, was also criticised (Congreso de los Diputados, 2000a: 677; Portilla, 2000: 26). The PSOE shared Aznar's concerns about the potential loss of cohesion and structural funds for Spain (Congreso de los Diputados, 1997: 6666), but accused him of being incapable of defending cohesion funds in the face of pressure 
from Germany, and of being unable to present a case of it being in Europe’s interest to maintain a system of cohesion funding (Congreso de los Diputados, 1998a: 9105, 9106-9107). The PSOE was opposed to Aznar's support for military action against Iraq, owing to the absence of backing from the United Nations (Collado, 1998: 23; González, 1998: 1). Aznar’s policy on Kosovo did, by contrast, receive their support (Congreso de los Diputados, 1998a: 9107).

Aznar and Blair's alliance regarding Iraq and Kosovo was cemented by the fact that the opposition of the PSOE and Conservative party did not act as a constraining factor in the case of either leader. As far as Europe was concerned, the impact of Conservative opposition on Blair's policy was harder to judge, but owing to the relatively Eurosceptic nature of the British media and public, it seemed to be the case that Blair's emphasis on an intergovernmentalist EU and an EU defence force working within the NATO framework came about not only because of his desire to keep the EU as close to the United States as possible, but also to demonstrate to the Conservatives the extent of the United Kingdom's influence at EU level. Aznar's policy was not constrained by the PSOE, thus he was free to act in the way in which he saw fit to advance Spain's status in Europe. Aznar and Blair came together to send out the same message to their domestic opposition. Their policies were making a difference for both Spain and the United Kingdom on the world stage and in Europe, and it was this depiction of influence which gave the two leaders the necessary freedom to pursue their foreign policy preferences, regardless of the views of the opposition.

THE THREAT FROM DICTATORS, ROGUE STATES, TERRORISM AND WEAPONS OF MASS DESTRUCTION 
This factor is highly significant because it shows that Aznar and Blair's concerns about dictators, rogue states, terrorism, and weapons of mass destruction were already present before September 11; a point which is not emphasised in the existing literature. Aznar and Blair expressed their concerns about dictators in a similar way. They allied themselves closely with the United States on Iraq, and they held similar views about terrorism.

Blair made frequent references to the evil and brutal nature of Saddam Hussein, the need to threaten to use force against him, and the fact that the United States and the United Kingdom would take action should he fail to comply with UN Security Council resolutions (Hansard, 1998a: 2; 1998b: 3-5; 1998c: 2). Brutality was also mentioned by Blair in reference to Milosevic's treatment of the people of Kosovo, particularly regarding ethnic cleansing, and that the barbaric actions of this dictator justified the use of force in order to combat his behaviour (Hansard, 1999a: 1; 1999b: 1; 1999c: 1-2). Blair emphasised that there would be no compromise with Milosevic, and that the Serbian leader had to agree to the terms laid down by the international community, with no room for negotiation, for the NATO military action to end (Hansard, 1999c: 3, 4; Blair, 1999: 2).

Blair expanded these points into a broader application of his principles during his Chicago Club speech in 1999. His main concern was that the international community could no longer allow dictators to persecute their own people (Blair, 1999: 2). He used the examples of Saddam Hussein and Slobodan Milosevic to justify this new approach. Blair, furthermore, had labelled Saddam Hussein as being 'bad' back in 1997; a position which was seen as being exceptionally 
close to the foreign policy of the United States (Rentoul, 2001: 423). These characterizations were important, since they provided indicators that Blair was already thinking along similar lines to the United States with respect to the threat posed by dictators, particularly Saddam Hussein, long before September 11.

Aznar's concerns about Milosevic were very similar to Blair’s. Aznar placed a strong emphasis on the violation of human rights and the ethnic cleansing, making multiple references to this behaviour being the fundamental reason to justify NATO intervention (Aznar, 1999: 1; Congreso de los Diputados, 04/05/1999a: 12596). He was thus strongly in favour of the position taken by the United States administration to intervene under the auspices of NATO (Larraya and González, 1999: 1; Larraya, 1999: 1).

Another crucial link between Aznar and Blair was that they both wanted to send a strong message that acts of terrorism would not be tolerated. They had different priorities in relation to domestic terrorism, in that Blair's approach to dealing with Irish terrorism was one of dialogue, while Aznar ruled out any form of negotiation with the Basque separatist group ETA. Aznar's refusal to engage in dialogue continuing during the brief ceasefire period between September 1998 and November 1999 (Aznar, 2004: 222-223) further demonstrated the strength of his views. On the international stage the connection between the two leaders was extremely strong. Both were committed to taking action against terrorism, linking the threat from weapons of mass destruction to terrorists and rogue states. They thus held a shared perspective on the need to tackle threats to national and international security, and were drawn increasingly towards the position of the United States whenever it sought to take action against rogue states or terrorist groups. 
Blair was very concerned by the threat posed by weapons of mass destruction, particularly in relation to Iraq. Blair alleged that Saddam Hussein possessed a vast arsenal of weapons of mass destruction which he would use if given the chance (Hansard, 1998b: 1; 1998c: 2). The determination to prevent the Iraqi dictator from continuing to possess weapons of mass destruction unified the United States and the United Kingdom on foreign policy towards Iraq, as was demonstrated by Blair emphasising that the Americans shared his view regarding the use of air strikes against Iraq to damage its weapons of mass destruction programme (Hansard, 1998b: 2). This was a policy to which he remained committed, in spite of international isolation (Ahmed, Burke, and Vulliamy, 2001: 1). Blair also lost backing from European allies regarding the maintenance of the no fly zones:

'When I was in Paris in 1997/1998, there were constant tensions with the French over the enforcement of the no fly zone in Iraq, and whether we should continue with one in the north and one in the south, and whether that was looking too aggressive, given Saddam Hussein's policies. We and the Americans were quite positive about wanting to see a strengthening of the no fly zone. The French were more hesitant, so there were differences there over Iraq' (Jay, 2011).

Despite these divisions, Blair maintained his views and his support for the United States. His commitment to the United States was strengthened by the intelligence on the threat from terrorism and weapons of mass destruction. Blair was very conscious of the terrorist threat, owing to the attacks on US embassies in East Africa and on the USS Cole (Jay, 2011). It was, however, the intelligence regarding weapons of mass destruction which was of particular concern. Blair confided in Paddy Ashdown that the intelligence on Saddam Hussein's weapons of mass destruction was very worrying, and that he did not understand why other countries, 
such as France, were not concerned (Coughlin, 2006: 25-26; Dyson, 2009: 109-110; Seldon, 2005: 387). Blair’s support for US foreign policy also extended to taking action beyond Iraq. For example, he backed a US missile strike on a factory in Sudan suspected of producing weapons of mass destruction. Even once it became clear that there had been no evidence to support this suspicion, Blair remained stalwart in his backing for the United States, arguing that a strong message had been sent to terrorists (Rentoul, 2001: 424; Parmar, 2005: 229). Blair, moreover, became the driving force in the relationship between the United States and the United Kingdom regarding these dangers once George W Bush came to power, urging the US president to take action to combat the threat posed by weapons of mass destruction (Kampfner, 2004: 155).

Aznar's approach to tackling terrorism represented a further connection between himself and Blair, since Aznar wanted Spain, like the United Kingdom, to act as a driving force in influencing other member states to take seriously the threat posed by terrorism. This was evident from his first European Council meeting, where he argued that it was Spanish influence which played a significant role in convincing other member states of the importance of the fight against terrorism (Congreso de los Diputados, 1996: 690). Aznar emphatically ruled out any kind of negotiations with, or concessions to, terrorists (Ayllón, 1999: 18). Aznar’s views were influenced by the threat from ETA, who he insisted needed to be tackled aggressively (Aznar, 2000a: 5-6). Aznar's policy towards ETA received substantial support, particularly from France, but also, crucially, from the United States. Aznar also developed a strong relationship with Gerhard Schröder regarding cooperation in the fight against terrorism. The connection between Aznar and Blair is also shown by the Spanish leader's efforts to persuade Bush that it was necessary for the United States to support Spain in the struggle against terrorism (Woodworth 2004: 13). It was the establishment of anti-terrorist cooperation with Bush which 
was most warmly welcomed by the Spanish leader (Egurbide, 2001a: 1), thus emphasising the extent to which Aznar prioritised his relationship with the United States.

Aznar and Blair were strong supporters of US foreign policy on terrorism and weapons of mass destruction. They also brought these issues to the attention of the White House once Bush became president, which is important because it underlines the fact that they became more concerned with the role played by the United States in dealing with terrorism towards the end of this period. Aznar and Blair placed greater value on supporting the United States or receiving its backing when it came to formulating their foreign policy than on any support emanating from their European partners, thus demonstrating their commitment to the United States before the September 11 attacks.

\section{INCREASING INFLUENCE ON THE INTERNATIONAL STAGE}

The extent to which Aznar and Blair wanted to increase the prominence of Spain and the United Kingdom on the world stage represented another common factor between the two leaders. What was particularly striking was the way in which Aznar sought to model Spain's relationship with the United States along the lines of that which was enjoyed by the United Kingdom. Aznar's objective of making Spain a global player was especially significant, for it was unprecedented in the post-Franco democratic period, and highlighted just how close Aznar was to Blair and to the United States in terms of wanting to project power through foreign policy on the international stage. Both Aznar and Blair believed that it was necessary to have 
a close relationship with the United States, in order to play a leading role in the world, which justified their support for US foreign policy.

Blair championed the United Kingdom's pivotal role in international affairs, citing, in particular, its roles as a permanent member of the UN Security Council, a nuclear power, and a leading player in NATO and the Commonwealth as giving it significant advantages which needed to be exploited to the full (Blair, 1998; 2000). He expressed his desire for the United Kingdom to have a strong presence on the world stage, emphasising that the purpose of a nation's foreign policy should be to use its power, strength, and influence, in order to further its interests and beliefs (Blair, 2000).

Aznar held a very similar position to Blair regarding his vision for Spain’s role on the global stage. He had long held the view that Spain was a very important country, referring to it as being one of the oldest nations in Europe, and one of the nations which had been a driving force in human history (Aznar, 1994: 29). He also made it clear that he no longer wanted Spain to be in the second division (Aznar, 2004: 151). Aznar thus aimed to strengthen Spain's presence in Europe and on the world stage (Aznar, 1996: 3; 1997: 5, 10, 11; 2000b: 3, 18). To help to achieve his goal, Aznar created a new foreign affairs council, which he himself chaired, which was designed to coordinate foreign policy, protect Spanish interests and increase Spain’s global standing (Aznar, 2000b: 18).

The theme of enhancing relations with the United States through strengthening the existing special relationship, in the case of Blair, or cultivating such a relationship, in the case of Aznar, 
is also significant within the context of increasing the global presence of both the United Kingdom and Spain. While ministers, officials, and Blair himself denied that the United Kingdom was resuming its cold war role of acting as NATO's bridge between the United States and Europe during the Kosovo conflict (Ellison and White, 1999: 1), there was no doubt that Blair wanted the special relationship to be an essential part of his foreign policy. This was demonstrated by the importance that Clinton attached to this relationship, and by Blair telling Bush that he wanted to maintain the unique relationship between the two countries (The Times, 2000: 1).

Aznar referred to the transatlantic destiny of Spain before he became prime minister (Aznar, 1994: 170). The relationship was viewed as important from multiple perspectives. These included the role of Spain in Latin America (Larraya and Valenzuela, 1997: 1), anti-terrorist cooperation, particularly regarding the detention of suspected ETA terrorists in the United States (ABC, 1998: 29), and the Spanish language, owing to the increasing number of Hispanics living in the United States (Portilla, 2000: 26). The most important factor, however, was that Aznar wanted to establish a special relationship with the United States (Portilla, 2000: 26). Achieving this ambition involved strengthening bilateral ties, and was reinforced through comments made by Bush and Aznar about their mutual desire to work more closely together (Egurbide, 2001b: 1).

Aznar and Blair held similar views on raising the profile of their respective countries on the global stage. Both emphasised the need to use their power and influence to protect their national interests, and to ensure that Spain and the United Kingdom had a strong presence in the international arena. This meant that both leaders not only held a similar vision for their 
respective countries on the world stage, but also led to Aznar mirroring Blair's approach towards the United States, in order to cultivate an unprecedented level of cooperation between Spain and the United States since the death of Franco. Aznar also noticeably positioned himself as being a key figure to act as a link between the United States, Latin America and the EU. He was, therefore, beginning to align Spanish foreign policy with that of the United Kingdom, thus forming a transatlantic partnership.

\section{THE DOMINANCE OF AZNAR AND BLAIR OVER FOREIGN POLICY MAKING}

Aznar and Blair established a very similar level of control over their foreign policy. As a result, they were able to ensure that their foreign policy reflected their preferences, leading to increased prime ministerial dominance over its direction. This factor is significant because the changes which Aznar and Blair made to the way in which foreign policy was handled facilitated the extent to which both leaders were able to support the United States following the terrorist attacks on September 11.

Blair opted to take much greater control of his European policy towards the end of his first term through the appointment of Sir Stephen Wall, a pro-European, to the role of 'European Enforcer' in the Cabinet Office. This move showed that Blair wanted to keep control of European policy in Downing Street, and to make more progress in this policy area (Ahmed and Hinsliff, 2000: 1). The reform of the Cabinet Office, which took place during the same year, was also designed to make Number Ten the dominant department in conveying the government's message (Heffernan and Webb, 2005: 37). This reform led to Blair becoming 
more presidential, since he subsequently received the majority of his foreign policy support within his inner circle (Seldon, 2008: 37), as was shown by the appointments of Sir Stephen Wall and Sir David Manning as his foreign policy adviser. The latter, in particular, was viewed as being more influential than the permanent secretary at the Foreign Office (Heffernan and Webb, 2005: 35).

The extent to which Blair took measures to ensure that all foreign policy was driven by Number Ten distinguishes him from previous prime ministers. Seldon (2008: 33-35), for example, argues that Blair's decision, after winning a second term, to replace Robin Cook with Jack Straw reflected Blair's desire to ensure that Cook did not acquire greater independence and authority by remaining in the post of foreign secretary, and the fact that Straw was more of a loyalist than Cook. Once this change had been made, Blair became his own foreign secretary, with neither Straw nor the Foreign Office taking a leading role in foreign policy decisions (Heffernan and Webb, 2005: 35; Seldon, 2008: 83). Blair had, therefore, gone further than any prime minister since Churchill in bypassing and overriding advice from the Foreign Office (Heffernan and Webb, 2005: 35).

Aznar demonstrated a similar desire to take control of foreign policy after having gained an absolute majority in parliament following the Spanish general election in 2000. The establishment of a new Foreign Affairs Council to support him in coordinating Spanish foreign policy demonstrated the extent to which it was being steered by those with close links to the Spanish prime minister, but the fact that it was also chaired by Aznar was crucial (El País, 2000: 1; Portilla, 2000: 26). By chairing the Council, Aznar sent a clear message that he wanted to shape Spanish foreign policy around his preferences, bypassing the Spanish foreign ministry 
completely. This message was underlined by Piqué, the Spanish foreign minister at this time, who stated that this new body would deal with those areas of policy which Aznar wanted it to address, as well as coordinate all the different ministries which carried out aspects of foreign policy (El País, 2000: 1). As chair of the Foreign Affairs Council, Aznar was also able to formulate foreign policy in a more presidential manner than had been the case during his first term (Balfour and Quiroga, 2007: 176).

These findings link to the presidentialization of the British and Spanish political systems. In the case of the UK, Heffernan and Webb (2005: 31) point out that the potential influence of a prime minister, when combined with close senior elected and non-elected allies, has done much to bypass members of the Cabinet, who are unable to influence government policy beyond the remit of their departments. In specific reference to Blair, they argue that he made more changes to the structure of Downing Street than any other prime minister before him by expanding the Prime Minister's Office significantly, and employing a relatively large number of special advisers (Heffernan and Webb, 2005: 34-35). In the case of Spain, Van Biezen and Hopkin (2005: 120) argue that it was difficult for Aznar to presidentialize his premiership, because he had stated that he would only serve two terms, meaning that it was the institutional and party based elements which enhanced his authority, rather than his status as prime minister. While this may have been the case in terms of domestic policy, the evidence provided in this article suggests that there was significant presidentialization of Aznar's foreign policy, owing to the concentration of power in his hands. Chari and Heywood (2009: 35) also challenge Biezen and Hopkin's conclusion, pointing out that the executive plays a dominant role in the policy making process, and that the democratic structure of Spain has been characterized by a high degree of power concentration. 


\section{CONCLUSION}

The five factors which explain the confluence of Aznar and Blair's foreign policy are summarised in the following table:

\begin{tabular}{|c|c|}
\hline Factor & Explanation \\
\hline Reform of the European Union. & $\begin{array}{l}\text { Aznar and Blair shared a goal of reforming } \\
\text { the European Union to go further in its } \\
\text { adoption of neo-liberal economic policies. } \\
\text { This resulted in the two leaders forming a } \\
\text { close partnership in their attempts to } \\
\text { implement economic reform. }\end{array}$ \\
\hline $\begin{array}{l}\text { The influence of party and parliamentary } \\
\text { support. }\end{array}$ & $\begin{array}{l}\text { Aznar and Blair benefited from strong } \\
\text { domestic support from their own parties and } \\
\text { a lack of constraint from the main opposition } \\
\text { for their foreign policy. Their domestic } \\
\text { dominance translated into an international } \\
\text { partnership which they used to highlight their } \\
\text { foreign policy success as a way to refute the } \\
\text { criticisms made by the main opposition. }\end{array}$ \\
\hline $\begin{array}{l}\text { The threat from rogue states, terrorism, and } \\
\text { weapons of mass destruction. }\end{array}$ & $\begin{array}{l}\text { Aznar and Blair held very strong views about } \\
\text { the need to take action against terrorists and }\end{array}$ \\
\hline
\end{tabular}




\begin{tabular}{|c|c|}
\hline & $\begin{array}{l}\text { rogue states. They were also both very } \\
\text { concerned about the threat that they posed } \\
\text { and about the possibility of either obtaining } \\
\text { or using weapons of mass destruction. This } \\
\text { resulted in their alliance becoming very } \\
\text { strong and led to them moving even further } \\
\text { towards the United States, including urging } \\
\text { the US administration to be more proactive } \\
\text { in some aspects of its foreign policy. }\end{array}$ \\
\hline Increasing influence on the world stage. & $\begin{array}{l}\text { Aznar and Blair both wanted to increase the } \\
\text { international influence and presence of their } \\
\text { respective countries on the world stage. } \\
\text { Their shared desire led to even closer } \\
\text { international cooperation between the two, as } \\
\text { they sought to assert their national interests } \\
\text { globally. }\end{array}$ \\
\hline $\begin{array}{l}\text { The dominance of Aznar and Blair over } \\
\text { foreign policy making. }\end{array}$ & $\begin{array}{l}\text { Aznar and Blair established extensive control } \\
\text { over their foreign policy making. This } \\
\text { concentration of decision-making in their } \\
\text { hands resulted in the two leaders formulating } \\
\text { foreign policy in a very similar way, thus } \\
\text { highlighting how they came to share the } \\
\text { same approach on the international stage. }\end{array}$ \\
\hline
\end{tabular}


The combination of these factors is highly salient in explaining how Aznar and Blair were able to forge such a close alliance and adopt a pro-US foreign policy. The occurrence of these factors in such a short period of time is also significant, for it demonstrates how it was the confluence which resulted in their collective impact being so important. It is vital to highlight the often overlooked point that their relationship had such a strong start at EU level, where their shared preference for economic reform was the catalyst to enhancing their personal chemistry. Aznar and Blair were able to do business with each other in the European Union, which was in contrast to their relationships with French and German leaders, thus they had a natural inclination to work together to reform the European Union in a way which suited their preferences. The fact that the extent to which they wished to liberalise the EU's economic policy was opposed by France and Germany served to strengthen their alliance, and shift their perspective further towards the United States as they sought to counter-balance Franco-German dominance of the European Union. This alliance in the European Union is, therefore, critical when explaining their adoption of a pro-US foreign policy.

Their alliance in the European Union helped to bolster their domestic standing, since both were able to deflect criticisms from the main opposition party about their European policy. This was because they could argue that they were playing a leading role in Europe and setting the agenda. The fact that Aznar and Blair's foreign policy beyond the European Union was also increasing the prominence of Spain and the United Kingdom on the world stage provided them with a similar line of defence against any opposition critique of their policy. Both countries were becoming influential at an international level, and Aznar and Blair asserted that this reflected the success of their foreign policy. 
It was Aznar and Blair's common ground regarding the various threats posed by terrorism, rogue states and weapons of mass destruction which drew them closer together on the global stage. It also further strengthened their ties to the United States, because they viewed having a close relationship with the US government as being the only way to achieve their foreign policy objectives. This explains the extent to which Aznar and Blair were prepared to back the US in taking action against Iraq, and the reason why both leaders sought to persuade the United States to commit to leading the fight against terrorism and rogue states.

Staying close to the United States in supporting its foreign policy was also viewed as a way to bolster the status of Spain and the United Kingdom by Aznar and Blair, as well as to influence US foreign policy when necessary. Having a strong relationship with the United States also augmented the international standing of both countries. This shared vision of the projection of power and influence also further served to demonstrate the extent to which Aznar and Blair had adopted the same approach to foreign policy. Such an approach was to have significant implications for decision-making post September 11, but its roots were to be found before these attacks took place.

Aznar and Blair facilitated the shift in their foreign policy towards the United States by ensuring that they controlled foreign policy decision-making. This control was vital in ensuring that any constraints or concerns were marginalised, and that it was feasible for decisions to be taken based on advice coming from a small inner circle. The extent to which Aznar and Blair strengthened their hold over decision-making in this area was vital to ensuring that they were masters of their own destiny, especially when it came to having the necessary freedom to adopt a pro-US foreign policy. 
It is clear that 3 March 1996 - 10 September 2001 represents a crucial period in explaining Aznar and Blair's adoption of a pro-US foreign policy. While it remains the case that September 11 constitutes a critical juncture in accounting for the foreign policy of the two leaders, the significance of factors before the attacks should not be overlooked. The foundations of the Aznar - Blair relationship were constructed long before September 11, and the confluence of factors identified in this article must, therefore, be taken into account when explaining their adoption of a pro-US foreign policy.

\section{REFERENCES}

ABC (1998), 'ETA tiene cada vez más dificultades para encontrar "santuarios” en el extranjero', http://hemeroteca.abc.es. Accessed 30 January 2011.

Ahmed, K. and Hinsliff, G. (2000), 'Europe “enforcer” to crack whip for Blair', http://www.guardian.co.uk. Accessed 21 February 2012.

Ahmed, K., Burke, J. and Vulliamy, E. (2001), 'Blair and Bush defy world fury', http://www.guardian.co.uk. Accessed 20 February 2012.

Anon (2011), Interview with author.

Ayllón, L. (1999), ‘Aznar recalca que no se puede transigir ni negociar con los terroristas’, http://hemeroteca.abc.es. Accessed 30 January 2011.

Aznar, J. M. (1994), España: La Segunda Transición, Madrid: Espasa Calpe.

Aznar, J. M. (1996), 'Discurso de José María Aznar en la sesión de investidura como presidente del gobierno’, http://www.jmaznar.es. Accessed 13 June 2012.

Aznar, J. M. (1997), 'Intervención de José María Aznar en el acto politico con motivo del primer aniversario de la victoria electoral del Partido Popular', http://www.jmaznar.es. Accessed 13 June 2012.

Aznar, J. M. (1999), 'Declaración de José María Aznar sobre el desarrollo del conflicto en Kosovo’, http://www.jmaznar.es. Accessed 13 June 2012. 
Aznar, J. M. (2000a), 'Conferencia de José María Aznar sobre España: libertad, pluralidad y constitución’, http://www.jmaznar.es. Accessed 13 June 2012.

Aznar, J. M. (2000b), 'Discurso de José María Aznar 'en el debate de investidura a la presidencia del gobierno’, http://www.jmaznar.es. Accessed 13 June 2012.

Aznar, J. M. (2004), Ocho Años de Gobierno: una vision personal de España, Barcelona: Planeta.

Balfour, S. and Quiroga, A. (2007), The reinvention of Spain, Oxford: Oxford University Press.

Black, I. (2000), 'Blair courts the little guys of Europe', http://www.guardian.co.uk. Accessed 21 February 2012.

Blair, T. (1998), 'Speech by the Prime Minister on foreign affairs, Tuesday 15 December 1998’, http://keeptonyblairforpm.wordpress.com. Accessed 12 June 2012.

Blair, T. (1999), ‘Online NewsHour: The Blair Doctrine - 22 April 1999’, http://www.pbs.org. Accessed 13 October 2009.

Blair, T. (2000), 'PM's Mansion House Speech, 13 November 2000', http://keeptonyblairforpm.wordpress.com. Accessed 12 June 2012.

Brighty, D. (2012), Interview with author.

Chari, R. and Heywood, P. M. (2009), ‘Analysing the Policy Process in Democratic Spain', West European Politics, 32: 1, pp. 26-54.

Collado, A. (1998), 'Los socialistas no apoyarán al Gobierno en la crisis iraquí sin una resolución de la ONU’, http://hemeroteca.abc.es. Accessed 30 January 2011.

Congreso de los Diputados (1996), 'Pleno y Diputación Permanente Año 1996 VI Legislatura Número 17’, http://www.congreso.es. Accessed 13 June 2012.

Congreso de los Diputados (1997), 'Pleno y Diputación Permanente Año 1997 VI Legislatura Número 123’, http://www.congreso.es. Accessed 13 June 2012.

Congreso de los Diputados (1998a), 'Pleno y Diputación Permanente Año 1998 VI Legislatura Número 170’, http://www.congreso.es. Accessed 13 June 2012.

Congreso de los Diputados (1998b), 'Pleno y Diputación Permanente Año 1998 VI Legislatura Número 204’, http://www.congreso.es. Accessed 13 June 2012.

Congreso de los Diputados (1999a), 'Pleno y Diputación Permanente Año 1999 VI Legislatura Número 236’, http://www.congreso.es. Accessed 13 June 2012.

Congreso de los Diputados (1999b), 'Pleno y Diputación Permanente Año 1999 VI Legislatura Número 246’, http://www.congreso.es. Accessed 13 June 2012. 
Congreso de los Diputados (1999c), 'Pleno y Diputación Permanente Año 1999 VI Legislatura Número 281’, http://www.congreso.es. Accessed 13 June 2012.

Congreso de los Diputados (2000a), 'Pleno y Diputación Permanente Año 2000 VII Legislatura Número 17’, http://www.congreso.es. Accessed 13 June 2012.

Congreso de los Diputados (2000b), 'Pleno y Diputación Permanente Año 2000 VII Legislatura Número 52', http://www.congreso.es. Accessed 13 June 2012.

Congreso de los Diputados (2001), 'Pleno y Diputación Permanente Año 2000 VII Legislatura Número 74’, http://www.congreso.es. Accessed 13 June 2012.

Coughlin, C. (2006), American Ally, London: Politico’s.

Dáil Eireann (2001), ‘Stockholm European Council: Statements’, http://debates.oireachtas.ie. Accessed 1 May 2013.

Dyson, S. (2009), The Blair Identity: Leadership and Foreign Policy, Manchester: Manchester University Press.

Egurbide, P. (2001a), 'Washington ofrece su “cooperación y ayuda” para vencer al terrorismo', http://www.elpais.com. Accessed 11 February /2011.

Egurbide, P. (2001b), 'Bush afirma que considera a España “uno de los aliados más fiables de Estados Unidos”, http://www.elpais.com. Accessed 11 February 2011.

Ellison, M. and White, M. (1999), 'Blair and Cook deny rift with Clinton over Kosovo', http://www.guardian.co.uk. Accessed 21 February 2012.

González, M. (1998), ‘España califica el ataque de "necesario” mientras Francia y Alemania lo deploran’, http://www.elpais.com. Accessed 18 January 2011.

Gunther, R. and Montero, J. R. (2009), The Politics of Spain, Cambridge: Cambridge University Press.

Hansard (1998a), 'Iraq HC Deb 24 February 1998 vol 307 cc173-87', http://hansard.millbanksystems.com. Accessed 12 June 2012.

Hansard (1998b), 'Iraq HC Deb 16 November 1998 vol 319 cc607-23', http://hansard.millbanksystems.com. Accessed 12 June 2012.

Hansard (1998c), 'Iraq HC Deb 17 December 1998 vol 322 cc1097-111', http://hansard.millbanksystems.com. Accessed 12 June 2012.

Hansard (1999a), 'Kosovo HC Deb 23 March 1999 vol 328 cc161-74', http://hansard.millbanksystems.com. Accessed 12 June 2012.

Hansard (1999b), 'Berlin European Council and Kosovo HC Deb 29 March 1999 vol 328 cc731-48’, http://hansard.millbanksystems.com. Accessed 12 June 2012. 
Hansard (1999c), 'Kosovo HC Deb 13 April 1999 vol 329 cc19-23', http://hansard.millbanksystems.com. Accessed 12 June 2012.

Hansard (1999d), 'Special European Council (Tampere) HC Deb 19 October 1999 vol 336 cc253-65’, http://hansard.millbanksystems.com. Accessed 12 June 2012.

Hansard (1999e), 'Helsinki European Council HC Deb 13 December 1999 vol 341 cc21-40', http://hansard.millbanksystems.com. Accessed 12 June 2012.

Hansard (2000a), 'European Council (Lisbon) HC Deb 27 March 2000 vol 347 cc21-36', http://hansard.millbanksystems.com. Accessed 12 June 2012.

Hansard (2000b), 'Nice European Council HC Deb 11 December 2000 vol 359 cc349-69', http://hansard.millbanksystems.com. Accessed 12 June 2012.

Heffernan, R. and Webb, P. (2005), 'The British Prime Minister: Much More Than "First Among Equals"', in Poguntke, T. and Webb, P. (eds), The Presidentialization of Politics, Oxford: Oxford University Press, pp. 26-62.

Jay, M. (2011), Interview with author.

Kampfner, J. (2004), Blair’s Wars, London: The Free Press.

Larraya, J. M. (1999), 'Milosevic debe responder por "la limpieza étnica y el genocidio”, dice Aznar en Hungría’, http://www.elpais.com. Accessed 4 February 2011.

Larraya, J. M. and González, M. (1999), 'Aznar afirma que la decision de atacar "está tomada y el Gobierno español “la apoya”, http://www.elpais.com. Accessed 4 January 2011.

Larraya, J. M. and Valenzuela, J. (1997), 'Aznar y Clinton impulsarán con un "trabajo permanente” la coooperación en América Latina’, http://www.elpais.com. Accessed 28 January 2011.

El País (2000), 'El nuevo Consejo de Política Exterior pretende convertir a España en una potencia global’, http://www.elpais.com. Accessed 11 September 2009.

Pacheco Pardo, R. (2012), 'EU membership and the Europeanization of Spanish political parties', International Journal of Iberian Studies, 25: 1, pp. 3-19.

Parmar, I. (2005), “'I’m Proud of the British Empire”: Why Tony Blair Backs George W. Bush’, Political Quarterly, 76:2, pp. 218-231.

Portilla, M. (2000), 'España traza un plan estratégico exterior para ampliar su influencia en el mundo’, http://hemeroteca.abc.es. Accessed 30 January 2011.

Rentoul, J. (2001), Tony Blair Prime Minister, London: Time Warner.

Schreier, M. (2012), Qualitative Content Analysis in Practice, London: Sage.

Seldon, A. (2005), Blair, London: The Free Press. 
Seldon, A. (2008), Blair Unbound, London: Pocket Books.

Smith, J. (2005), ‘A missed opportunity? New Labour’s European Policy 1997-2005', International Affairs, 81:4, pp. 703-721.

The Times (2000), ‘Britain’s US links “will grow stronger”, http://www.lexisnexis.com. Accessed 7 March 2012.

Torreblanca, J. I. (2001), Ideas, preferences, and institutions: Explaining the Europeanisation of Spanish Foreign Policy, Oslo: ARENA, University of Oslo.

Van Biezen, I. and Hopkin, J. (2005), 'The Presidentialization of Spanish Democracy: Sources of Prime Ministerial Power in Post-Franco Spain’, in Poguntke, T. and Webb, P. (eds), The Presidentialization of Politics, Oxford: Oxford University Press, pp. 107-127.

Woodworth, P. (2004), ‘Aznar’s Legacy, Zapatero’s Prospects’, World Policy Journal, 21:2, pp. 7-26. 